J. Reprod. Fert. (1972) 28, 1-7

\title{
VAGINAL HISTOLOGY OF THE DOMESTIC PIG: HISTOMORPHOLOGY FROM BIRTH TO 8 YEARS WITH SOME CLINICAL ASPECTS
}

\author{
H. S. BAL AND R. GETTY* \\ Department of Veterinary Anatomy, College of Veterinary Medicine, \\ Iowa State University, Ames, Iowa 50010, U.S.A.
}

(Received 12th November 1970, accepted 25th June 1971)

\begin{abstract}
Summary. In a histomorphological study of the vagina of sixty-six sows of documented ages, known genetic background and dietary history, it was noted that a sub-epithelial elastic layer appeared after 1 year of age in the vaginal mucosa. Above 2 years of age, epithelial folds or invaginations were seen in the tunica mucosa as microcysts or cell nests. The inner circular layer of tunica muscularis consisted of equal amounts of fibrous tissue and smooth muscle, forming a fibromuscular layer. The ductus epoophori (canal of Gartner) persisted up to 8 years of age (maximum age studied). Evaginations as outgrowths of the epithelium of this canal were augmented with advancing age. The clinical or pathological significance of these mesonephric remnants in the vaginal wall of the aged sow should be borne in mind when diagnosing neoplasms of the vagina. Most of the vaginal arteries did not seem to be affected with intimal thickening to any great extent when compared to the arteries of the uterine tubes, uterus and cervix of the corresponding age groups.
\end{abstract}

\section{INTRODUGTION}

The vaginal histology of a number of domestic animals has received a general description in some textbooks (Trautman \& Fiebiger, 1957; Montane, Bourdelle \& Bressou, 1964). The descriptions, however, lack details relating to specific species of animals. Our study of vaginal sections from sixty-six pigs, ranging in age from birth to 8 years, revealed that the histology of the sow's vagina exhibited some interesting changes with age. Since the hog is being used more frequently as a laboratory animal for comparative studies in the paramedical professions, the authors felt there was a need to report their observations. Cyclic changes in the epithelium of the vagina of the sow have been investigated and reported by McKenzie (1926), Wilson (1926), Baker, Woehling, Casida \& Grummer (1953), DeBois, Muurling \& Wensing (1965), Done \& Heard (1968) and Bal, Wensing \& Getty (1969).

\footnotetext{
- The Editor regrets to report the death of Professor Getty on 18th February 1971, during the preparation of this paper for publication.
} 


\section{MATERIALS AND METHODS}

Tissues of the vagina were obtained from pigs of various breeds (Table 1) raised in a known environment and on a known diet at the swine farm of Iowa State University. These sows were selected solely on basis of age, and sows of

TABLE 1

AGE AND BREED DISTRIBUTION OF SOWS

\begin{tabular}{|c|c|c|}
\hline Breed & Age & No. of sows \\
\hline $\begin{array}{l}\text { Yorkshire } \\
\text { Yorkshire } \\
\text { York and Chester White } \\
\text { Duroc } \\
\text { W.D.D.P.L.* } \\
\text { Chester White } \\
\text { Pc-York., L.R.† } \\
\text { Duroc } \\
\text { Poland China Landrace } \\
\text { Yorkshire } \\
\text { Chester White } \\
\text { Pc-York., L.R. } \\
\text { Yorkshire } \\
\text { Pc-York., L.R. } \\
\text { York., L.R. } \\
\text { York., L.R. } \\
\text { York., L.R. } \\
\text { York., L.R. } \\
\text { Yorkshire } \\
\text { York., L.R. } \\
\text { York., L.R. } \\
\text { Poland China } \\
\text { Landrace } \\
\text { York., L.R. } \\
\text { York., L.R. } \\
\text { Chester White } \\
\text { York., L.R. } \\
\text { Landrace } \\
\text { Chester White } \\
\text { Chester White } \\
\text { Landrace } \\
\text { Farmer's hybrid } \\
\text { Landrace } \\
\text { Yorkshire } \\
\text { Landrace } \\
\text { York., L.R. } \\
\text { Landrace } \\
\text { Landrace } \\
\text { York., L.R. } \\
\text { Ghester White } \\
\text { Yorkshire } \\
\text { Landrace }\end{array}$ & $\begin{array}{l}1 \text { day } \\
1 \text { week } \\
2 \text { weeks } \\
1 \text { month } 1 \text { week } \\
1 \text { month } 1 \text { week } \\
2 \text { months } \\
2 \text { months } \\
2 \text { months } 2 \text { weeks } \\
2 \text { months } 2 \text { weeks } \\
3 \text { months } \\
3 \text { months } \\
4 \text { months } \\
6 \text { months } \\
6 \text { months } \\
1 \text { year } 2 \text { months } \\
1 \text { year } 3 \text { months } \\
1 \text { year } 5 \text { months } \\
1 \text { year } 7 \text { months } \\
1 \text { year } 8 \text { months } \\
2 \text { years } 9 \text { months } \\
2 \text { years } 2 \text { months } \\
2 \text { years } 6 \text { months } \\
2 \text { years } 6 \text { months } \\
2 \text { years } 7 \text { months } \\
2 \text { years } 9 \text { months } \\
2 \text { years } 10 \text { months } \\
3 \text { years } 1 \text { month } \\
3 \text { years } 7 \text { months } \\
3 \text { years } 7 \text { months } \\
4 \text { years } \\
4 \text { years } 6 \text { months } \\
4 \text { years } 6 \text { months } \\
4 \text { years } 7 \text { months } \\
4 \text { years } 11 \text { month } \\
6 \text { years } \\
6 \text { years } \\
6 \text { years } 3 \text { months } \\
6 \text { years } 5 \text { months } \\
6 \text { years } 9 \text { months } \\
7 \text { years } 9 \text { months } \\
8 \text { years } \\
8 \text { years }\end{array}$ & $\begin{array}{l}3 \\
3 \\
3 \\
2 \\
1 \\
3 \\
1 \\
2 \\
1 \\
1 \\
2 \\
2 \\
1 \\
1 \\
2 \\
1 \\
1 \\
1 \\
1 \\
2 \\
2 \\
1 \\
2 \\
1 \\
1 \\
1 \\
1 \\
3 \\
1 \\
2 \\
1 \\
3 \\
1 \\
2 \\
2 \\
1 \\
1 \\
1 \\
1 \\
2 \\
1 \\
1\end{array}$ \\
\hline Total & & 66 \\
\hline
\end{tabular}

* Chester White-Duroc $\times$ Poland China-Landrace.

$\uparrow$ Poland China Yorkshire $\times$ Landrace.

equal age were also of equal parity. The pigs were killed by electrocution and exsanguinated. After the bleeding ceased, the genital tract was exposed and tissues were collected from all parts of the vagina and fixed in $10 \%$ buffered formalin solution within $15 \mathrm{~min}$ of death. These tissues were not confined to 
any specific area for any age group. Tissues were processed and embedded in paraffin wax in accordance with the standard histological techniques. Sections from 6 to $8 \mu \mathrm{m}$ in thickness were prepared and stained with the following: (1) haematoxylin and eosin; (2) Crossman's modification of Mallory's Triple stain (Crossman, 1937); (3) liver technique using the combination of Weigert's, Van Gieson's and Heidenhain's stains initially developed and used by Getty (1945) and described in detail by Bal (1966); (4) Verhoeff's elastic stain using Picro-indigo carmine and Van Gieson as counter stains (Pearse, 1961); (5) periodic acid-Schiff stain.

\section{RESULTS}

Observations (Table 2) have been made on tissues from animals in the prepubertal period (birth to 4 months of age) and postpubertal period (after 4 months of age).

TABLE 2

SYNOPSIS OF VAGINAL MORPHOLOGY OF THE SOW WITH AGE

\begin{tabular}{|c|c|c|c|c|c|c|}
\hline Age & $\begin{array}{c}\text { No. of } \\
\text { specimens }\end{array} \mid$ & Epithelium & $\begin{array}{c}\text { Sub- } \\
\text { epithelial } \\
\text { elastic } \\
\text { lamina }\end{array}$ & $\begin{array}{l}\text { Epithelial } \\
\text { cysts on the } \\
\text { mucosa }\end{array}$ & $\begin{array}{l}\text { Fibro- } \\
\text { muscular } \\
\text { layer }\end{array}$ & $\begin{array}{l}\text { Canals of Gartner } \\
\text { (ductus epoophori) }\end{array}$ \\
\hline $\begin{array}{l}\text { Birth to } 4 \\
\text { months }\end{array}$ & 22 & $\begin{array}{l}\text { No cyclic } \\
\text { changes }\end{array}$ & $\begin{array}{l}\text { Not } \\
\text { present }\end{array}$ & Not present & Present & $\begin{array}{l}\text { Present without any } \\
\text { evaginated outgrowth } \\
\text { of epithelium }\end{array}$ \\
\hline $\begin{array}{l}4 \text { months to } \\
2 \text { years }\end{array}$ & 10 & $\begin{array}{l}\text { Cyclic } \\
\text { changes seen } \\
\text { according to } \\
\text { stage of the } \\
\text { oestrous cycle }\end{array}$ & Present & $\begin{array}{l}\text { Become very } \\
\text { apparent at } \\
2 \text { years age }\end{array}$ & Present & $\begin{array}{l}\text { Present with slight } \\
\text { evaginated outgrowth } \\
\text { of epithelium }\end{array}$ \\
\hline 2 to 8 years & 34 & $\begin{array}{l}\text { Cyclic } \\
\text { changes seen }\end{array}$ & Present & $\begin{array}{l}\text { Present and } \\
\text { conspicuous }\end{array}$ & Present & $\begin{array}{l}\text { Increased outgrowth } \\
\text { of epithelium with } \\
\text { advancing age }\end{array}$ \\
\hline
\end{tabular}

\section{Prepubertal period (birth to approximately 4 months)}

The vagina during this period is in the growing stage.

The epithelium of the tunica mucosa consisted of three to five layers of stratified squamous cells. The mucosa-submucosa had areolar tissue which appeared spongy due to the presence of many blood vessels (Pl. 1, Fig. 1). Both the arteries and veins were lined only with endothelium, being devoid of a muscular coat.

Three layers of smooth muscle fibres constituted the tunica muscularis: (a) the innermost layer of smooth muscle fibres was arranged in a longitudinal pattern and appeared as scattered bundles, (b) the circular layer of muscle fibres surrounded the inner longitudinal layer. In this layer, the circular muscle fibres were mixed with an equal amount of connective tissue. Due to the presence of considerable amounts of connective tissue in this layer, the authors have called this the 'fibromuscular layer' which was seen throughout the life of the animal, and (c) the outer longitudinal muscle layer was composed of strands of smooth muscle fibres surrounding the fibromuscular layer. 
The ductus epoophori (Gartner's canals or mesonephric ducts) persisted after birth in the tunica mucosa close to the tunica muscularis (Pl. 1, Fig. 2) along the whole length of the vagina.

Above 2 months of age, the lamina propria appeared spongy and was similar in structure to erectile tissue. More adipose tissue was seen in the adventitia which had vessels, nerves and ganglia.

At 3 months of age, a few invaginated folds of epithelium appeared in the subepithelial mucosa. Three layers of muscle, the inner longitudinal layer, the middle circular layer rich in fibroelastic tissue (fibromuscular layer), and an outer longitudinal layer became distinct.

The vessels in the mucosa constituted a single layer of endothelium. At the time of sexual maturity, characterized by the onset of the oestrous cycle, the arteries acquired a muscular coat and could be distinguished from the veins, most of which did not have a muscular coat and consisted only of a single lining of endothelial cells. The arteries were, however, much larger than the capillaries and had a much greater calibre.

\section{Puberty (approximately 4 to 6 months)}

Above the age of 4 months, the number of cell layers of the vaginal epithelium depended on the stage of the oestrous cycle. In the subepithelial mucosa, mononuclear leucocytes and plasma cells were generally present. A subepithelial lamina of elastic tissue was present from this age onwards. The canals of Gartner were also present in the vagina of all specimens studied. Clear cells were present in the epithelium.

\section{Postpubertal period (approximately 6 months and more)}

The epithelium of the vagina changes according to the period of the oestrous cycle induced by the ovarian hormones. Details of the epithelial changes have been previously described by the authors (Bal et al., 1969). Above the age of 1 year, the presence of an elastic layer was very discernible under the epithelium (Pl. 1, Fig. 3). It may be called a subepithelial elastic fibrous layer (as the fibres of this layer were positive to elastic stains) according to its relation to the overlying epithelium.

At approximately 2 years of age, the vaginal mucosa was thrown into many folds which appeared as invaginations of the surface epithelium into the mucosal connective tissue (Pl. 1, Fig. 4; Pl. 2, Fig. 5). These invaginated epithelial folds

\section{EXPLANATION OF PLATE I}

Fig. 1. Pig (Yorkshire), 1 day old. A section of the vagina showing a stratified epithelium and a spongy mucosa with many vascular channels simulating cavernous spaces of the erectile tissue. $\mathrm{H}$ and $\mathrm{E}$ stain. $\times 125$.

FIG. 2. Pig (Chester White), 3 months old. A section of the vagina showing an embryonic mesonephric duct (canal of Gartner) in the wall. $\mathrm{H}$ and $\mathrm{E}$ stain. $\times 125$.

Fig. 3. Pig (Landrace), 4 years 7 months old. A section of the vagina showing the subepithelial elastic layer (arrow). Weigert's, Van Gieson's and Heidenhain's stain. $\times 315$.

FIG. 4. Pig (York., L.R.), 2 years 7 months. A section of the vagina showing epithelial invaginations into the mucosa forming microcysts. Weigert's, Van Gieson's and Heidenhain's stain. $\times 125$. 


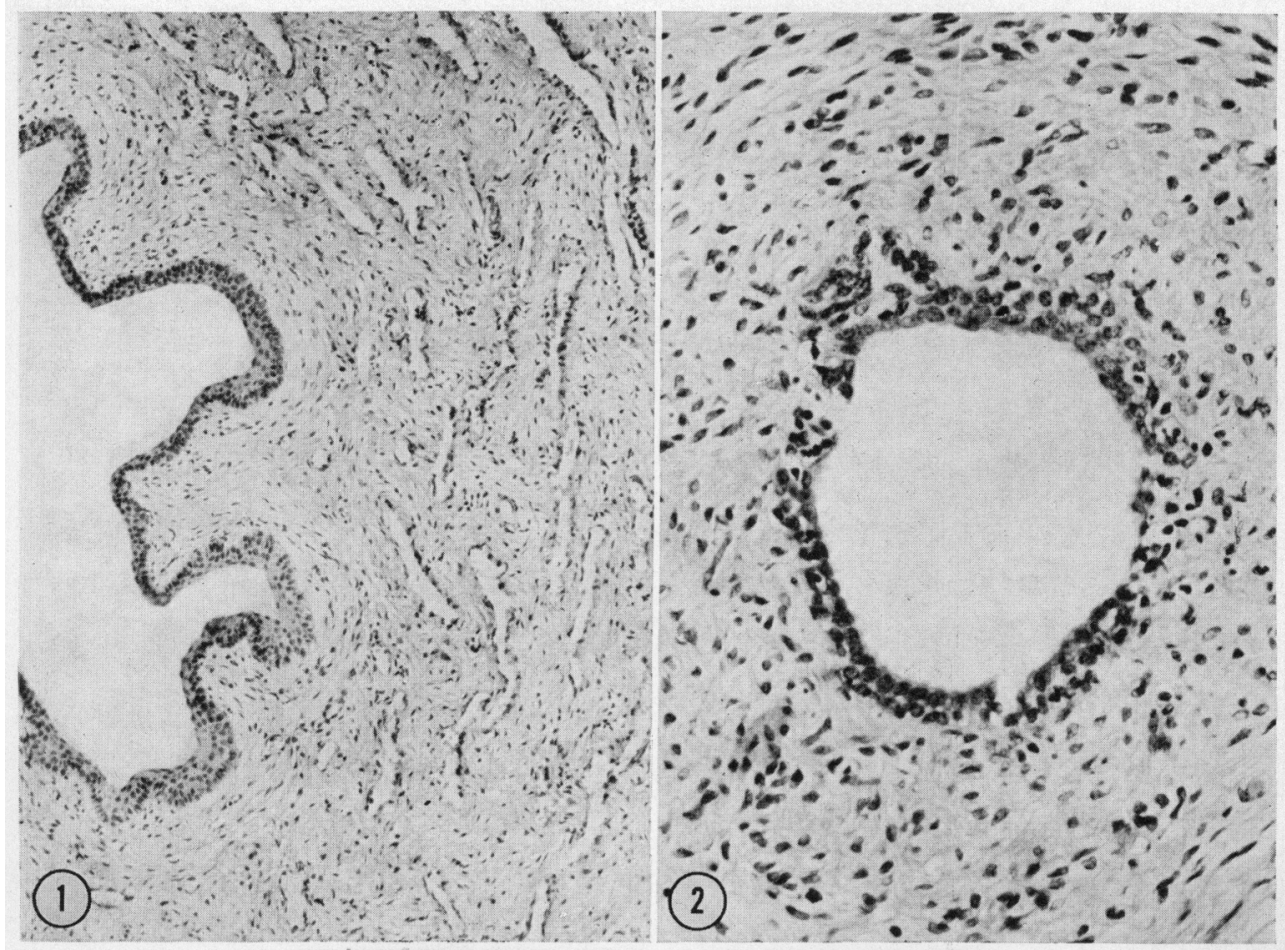

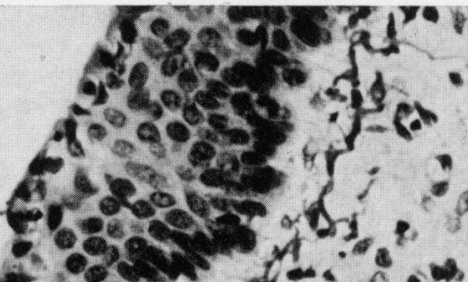

20.9-2 Cace
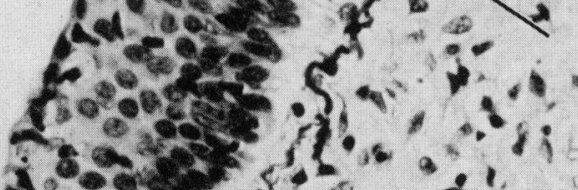

\$8\%

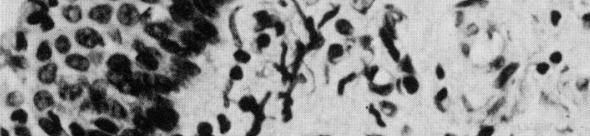
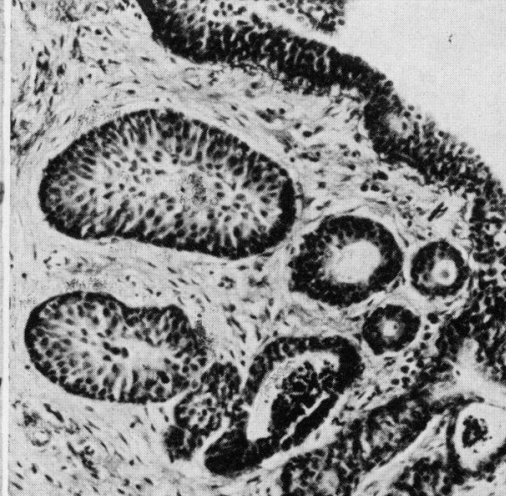

the

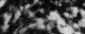




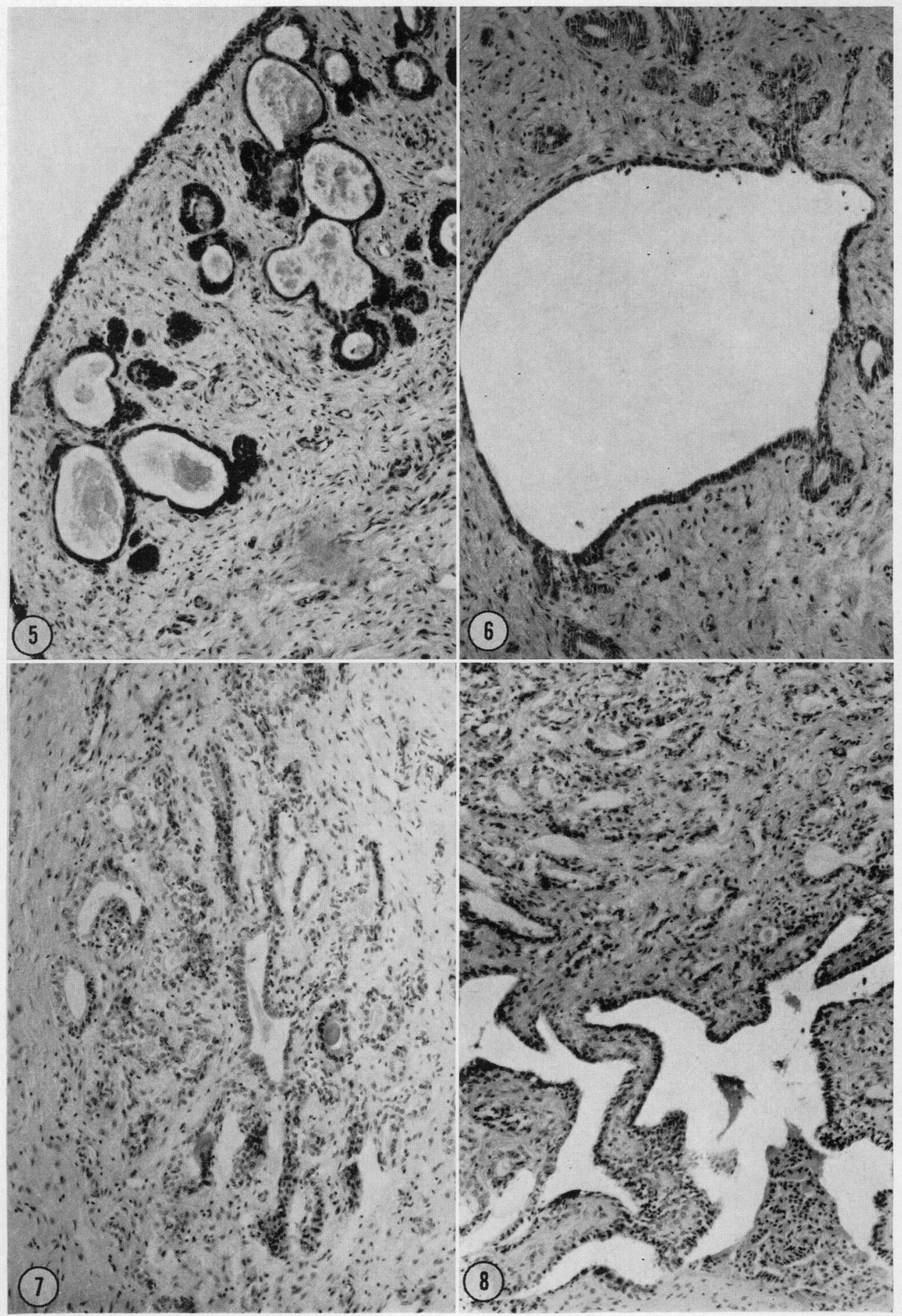


appeared to increase with advancing age. As the vaginal epithelium is subjected to change according to the stage of the oestrous cycle, the deeper parts of these folds accumulated desquamated surface epithelium, which may close the folds in the superficial areas. The deeper parts then appeared as microcysts or cell nests containing débris of desquamated cells (Pl. 2, Fig. 5). Therefore, the superficial part of the vaginal mucosa was studded with many invaginated epithelial nests or microcysts containing cell débris (Pl. 1, Fig. 4; Pl. 2, Fig. 5).

Close to the tunica muscularis, the canals of Gartner were seen even in the vagina of the 8-year-old sows. The mucosa of these canals appeared to be thrown into folds. In the younger age groups, no such folds of epithelium of these canals were observed (Pl. 1, Fig. 2). About the age of 2 years, outgrowths from these canals were manifested as small evaginations (Pl. 2, Fig. 6). The outgrowths appeared to increase with advancing age and over 6 years of age these structures somewhat resembled the collecting ducts of the medulla of the kidney (Pl. 2, Figs. 7 and 8). Rudimentary Gartner's ducts have been observed in the cervix of the aged sow (Bal, 1969). Thus, anywhere along the uterus, cervix or vagina, a tumour or cyst from tissue of mesonephric origin may develop.

The muscle layers (described under the prepubertal period) become more prominent as the sow ages.

Intimal thickening of small arterioles was seen in a few arterioles in the tunica muscularis. Most of the vaginal arteries did not seem to be affected with intimal thickening to any great extent compared to the arteries of the uterine tubes, uterus and cervix of the corresponding age groups (Bal, 1969).

\section{DISCUSSION}

No change in the vaginal epithelium was observed in sows below the age of puberty (4 to 6 months) and the changes which occur during the oestrous cycle have been described by the authors cited in the Introduction. The subepithelial elastic layer was observed as a constant feature after the attainment of sexual maturity. It stained positively with Verhoeff's elastic stain as well as a modification of Weigert's, Van Gieson's and Heidenhain's stain (Getty, 1945) (P1. 1, Fig. 3).

It seems probable that the epithelial nests or microcysts described in the sows of approximately 2 years of age arose from invaginations of the surface

\section{EXPLANATION OF PLATE 2}

FIG. 5. Pig (Yorkshire), 4 years 11 months. A section of the vagina showing the same features as in Pl. 1, Fig. 4. $\mathrm{H}$ and $\mathrm{E}$ stain. $\times 125$.

Fic. 6. Pig (York., L.R.), 2 years old. A section of the vagina showing small epithelial outgrowths or evaginations from the mesonephric duct. Weigert's, Van Gieson's and Heidenhain's stain. $\times 125$.

Fic. 7. Pig (Landrace), 6 years 3 months old. A section of the vagina showing further epithelial outgrowths from the mesonephric duct (canal of Gartner) forming small tubular structures. $\mathrm{H}$ and $\mathrm{E}$ stain. $\times 125$.

FIG. 8. Pig (Landrace), 8 years. A section around the mesonephric duct of the vagina. More epithelial outgrowths are evident as compared to P1. 2, Fig. 7. H and E stain. $\times 125$. 
epithelium, followed by contact forming between the epithelial surfaces. If the superficial part of the neck of this tubular infolding became blocked by the desquamating epithelial cells after oestrus, the lower part of the tubular fold might then become distended with cell débris, thus appearing as a cyst (PI. 1, Fig. 4; Pl. 2, Fig. 5). These microcysts should not be regarded as a pathological feature.

The ductus epoophori in the young animals below 1 year of age (Pl. 1, Fig. 2) was lined with stratified ciliated cuboidal epithelium of two to three layers in thickness. The epithelial lining became more folded with advancing age (compare Pl. 1, Fig. 2 with Pl. 2, Figs. 6, 7 and 8).

The fibromuscular layer described in this study has been considered in the past as an inner circular layer composed of smooth muscle fibres only. This layer, according to the view of the present authors, is the strongest layer of fibrous (collagenous and elastic) and muscular tissue of the vaginal wall (P1. 3, Fig. 9). During parturition, it can withstand excessive expansion, the reinforcement by fibrous tissue preventing rupture of the vaginal wall. Smooth muscle alone does not appear to be a tissue of tough enough texture to withstand excessive expansion during the passage of fetuses* through the vagina of the sow.

Mesonephric adenocarcinomata of the vagina developing from mesonephric rests (Wolffian or Gartner's) of the vaginal wall have been described by Janovski \& Dubrauszky (1967). Two cases of clear cell adenocarcinoma of the cervix and vaginal vault of mesonephric origin have been documented by Truskett \& Constable (1968). However, the authors report that cervical and vaginal mesonephric tumours were of far rarer occurrence than was the case for ovarian 'mesonephromas'. Eastman \& Hellman (1966) state that vaginal cysts, usually embryological rests (Gartner's or Mullerian) may be of sufficient size to cause serious dystocia. Although neoplasms of the canine uterus, vagina and vulva have been reported (Brodey \& Roszel, 1967), there is a paucity of data available on the reproductive tract of the ageing sow.

The clinical or pathological aspects of the mesonephric remnants in the vaginal wall of the sow should be borne in mind while diagnosing neoplasms of the vagina or cervix. Nephromata of embryonic origin were seen to develop in pigs under 1 year of age (Moulton, 1961). Novak, Woodruff \& Novak (1954) have suggested that mesonephric neoplasms of the human cervix and vagina may be grouped together because a good many of them involve both these locations and the primary seat of origin is not always known. Mesonephric adenomata, benign in nature, may appear clinically as ulcers but ulcerative forms may also be assumed by rare malignant lesions arising from mesonephric elements in this location. Cysts and cystadenomata may also be common in women and it is sometimes difficult to differentiate between normal and abnormal forms (Huffman, 1948). In the present investigation, no cysts were observed in the sows of any age groups. The incidence of neoplasms of mesonephric origin have not been reported in the literature in older pigs since hogs are slaughtered between the ages of 6 months and 1 year and older breeding animals are seldom retained beyond the age of 5 years.

* Following a recent decision of the Journal's Advisory Committee, the spelling of 'foetus' in this and subsequent issues will revert to the original, and etymologically more correct, form of 'fetus'. 


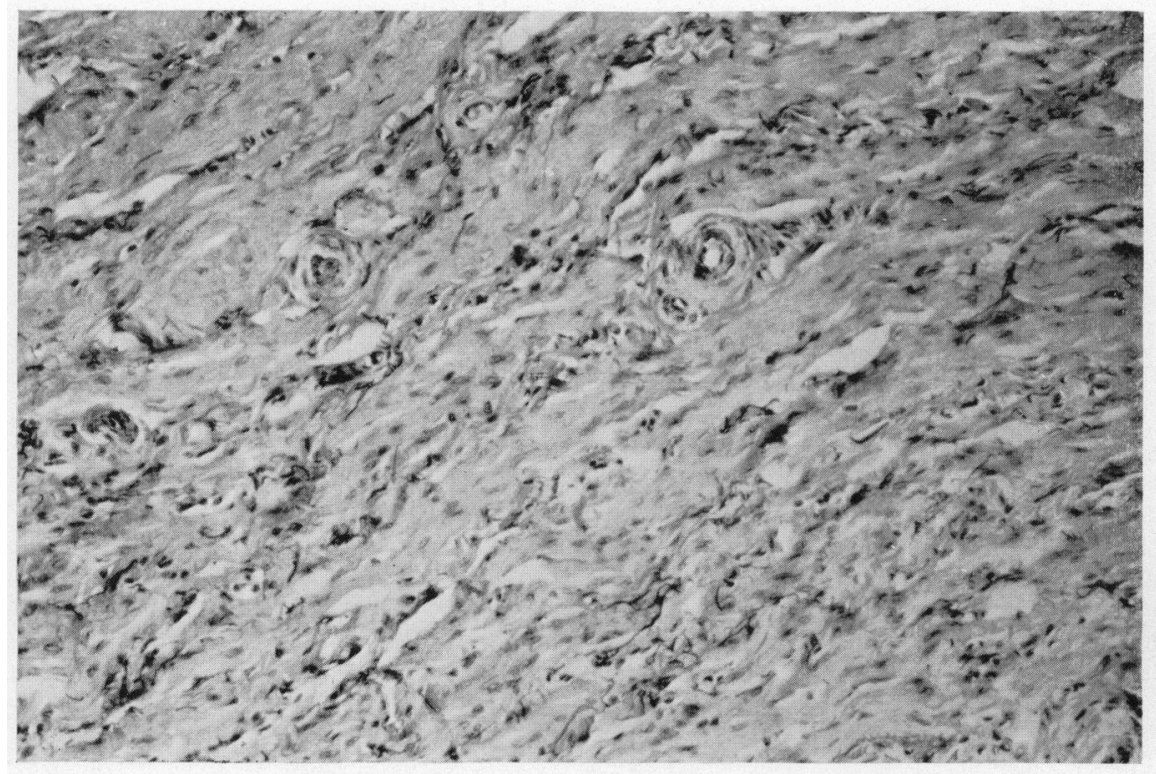

FIG. 9. Pig (Chester White), 4 years. A section of the vagina showing the fibromuscular layer of the tunica muscularis. Verhoeff's elastic stain. $\times 143$. 
This investigation was supported in part by the U.S. Public Health Service Research Grants Nos. HE-04487 and HD-00041 from the National Institute of Health. Taken in part from a 1969 Ph.D. thesis by Dr Bal from the Department of Veterinary Anatomy, College of Veterinary Medicine, under the direction of Dr Getty.

The authors wish to acknowledge the helpful cooperation and assistance of Dr W. E. Haensly in the collection of the organs and tissues. Sincere appreciation is also extended to Dr D. F. Cox, Dr V. W. Hays, Dr L. N. Hazel and Dr V. C. Speer of the Department of Animal Science, Iowa State University, for making available the hogs used in this study. Appreciation is also extended to Miss R. Aspengren for technical assistance. Grateful acknowledgment is made to Miss J. Brown, Research Assistant, for helpful suggestions and to Miss Linda Erickson for carefully typing this manuscript.

\section{REFERENCES}

Baker, L. N., Woehling, H. L., CAsida, L. E. \& Grummer, R. H. (1953) Occurrence of estrus in sows following parturition. 7. Anim. Sci. 12, 33.

BAL, H. S. (1966) Morphological changes in the ovaries of the sow (Sus scrofa domesticus) as influenced by age from birth to eight years. M.S. thesis, Iowa State University of Science and Technology, Ames.

BAL, H. S. (1969) Histomorphological changes in the tubular genitalia of the sow (Sus scrofa domesticus) as influenced by age. Ph.D. thesis, Iowa State University of Science and Technology, Ames.

Bat, H. S., Wensing, G. J. G. \& Getry, R. (1969) Morphological changes seen in the vaginal epithelium and ovary of swine of various ages as a means of evaluating cyclic phases. Iowa St. $\mathcal{F}$. Sci. 46, 341 .

Brodey, R. S. \& Roszer, J. F. (1967) Neoplasms of the canine uterus, vagina, and vulva: A clinicopathologic survey of 90 cases. F. Am. vet. med. Ass. 151, 1294.

Crossman, G. (1937) A modification of Mallory's connective tissue stain with a discussion of principles involved. Anat. Rec. 69, 33.

DeBors, G. H. W., Muurling, F. \& Wensing, G. J. G. (1965) Histological pregnancy test in the sow. [In Dutch]. Tijdschr. Diergeneesk. 90, 1317.

Done, J. T. \& Hzard, T. W. (1968) Early pregnancy diagnosis in the sow by vaginal biopsy. Vet. Rec. 82, 64.

Eastman, N. J. \& Heldman, L. M. (1966) Williams obstetrics, 13th edn. Appleton-Century-Crofts, New York.

GETTY, R. (1945) Histopathology of a focal hepatitis and of its termination ("Sawdust" and "Telang" liver) in cattle. M.S. thesis, Iowa State University of Science and Technology, Ames.

Hurpman, J. W. (1948) Mesonephric remnants in the cervix. Am. 7. Obstet. Gynec. 56, 23.

JaNovskr, N. A. \& DUBRAUSzKY, V. (1967) Atlas of gynecologic and obstetric diagnostic histopathology. Blakiston Division, McGraw-Hill, New York.

MaKenzie, F. (1926) The normal oestrus cycle in the sow. Res. Bull. Mo agric. Exp. Stn, 86.

Montane, L., Bourdelle, E. \& Bressou, C. (1964) Anatomie regionale des animaux. Part III. Le porc. J. B. Baillière et Fils, Paris.

Moulton, J. E. (1961) Tumors in domestic animals. University of California Press, Berkeley and Los Angeles.

Novak, E., Woodrufr, J. D. \& Novak, E. R. (1954) Possible mesonephric origin of certain female genital tumors. Am. 7. Obstet. Gynec. 68, 1222.

Pearse, A. G. E. (1961) Histochemistry: theoretical and applied, 2nd edn. Little, Brown and Co., Boston, Mass.

Trautman, A. \& Fiebiger, J. (1957) Fundamentals of the histology of domestic animals, 9th edn. McGrawHill, Ithaca, New York.

Truskett, I. D. \& Constable, W. C. (1968) Clear cell adenocarcinoma of the cervix and vaginal vault of mesonephric origin. Cancer, 21, 249.

WiLson, K. M. (1926) Histological changes in the vaginal mucosa of the sow in relation to the oestrous cycle. Am. F. Anat. 37, 417. 